\title{
Analysis of various parameters affecting weir design and fabrication of Weirs: An Overview
}

\author{
B. Rao Vanishree ${ }^{1}$ and R. Manjula ${ }^{1 *}$ \\ ${ }^{1}$ Sahyadri college of Engineering And Management, Adyar, Mangaluru-575009, Karnataka, India
}

\begin{abstract}
Several geometric parameters influence weir discharge and it is explained in our present study. The PK weir is more efficient than rectangular labyrinth weir due to reduction in entrance losses of PK weir inlet key geometry. PK weir is a type of labyrinth weir with variation in angle. Therefore, in this paper we also discuss about labyrinth weir. PKW are compatible for constructing on existing or new spillway with lesser space requirement and structural stability. PKW are installed in order to increase the discharge capacity for a given footprint area. PKW is used to increase the overflow capacity of existing dams such as, Hazelmare dam (South Africa), Dartmouth dam (Australia). Trapezoidal piano key weirs have higher discharge efficiency than rectangular weirs and it is due to interference wedge. $\mathrm{C}_{\mathrm{d}}$ of TPKW is influenced by $\mathrm{L} / \mathrm{W}$ but $\mathrm{W}_{\mathrm{i}} / \mathrm{W}_{\mathrm{o}}$ has least effect.
\end{abstract}

\section{Introduction}

Weirs are ordinarily used to avoid flooding, measure water discharge and help render waterways more safe by watercraft. A few dams have little spillway limits contrasted with configuration surges. Weir structures are utilized as a part of channel, flow, and store applications for flow estimation, flow redirection, and discharge control, and they are regularly intended for nothing flow conditions i.e., the surface of tail water is underneath the weir crest. Weir is utilized as flow control.

\subsection{Submergence}

At the point when tail water surpasses crest height the weir is submerged [1]. Submergence will probably be of concern when low-head control structures are introduced on mellow sloping waterways or channels with tightening influences and so on. When all is said in done strong solid weirs are utilized, yet these days, they are made of free stones, for example, gabion weir, since the last can better meet normal and natural prerequisites. It limits sedimentation and eutrophication is an impoundment. Weir submergence is found in abundance in-flow vegetation downstream. At low submergence levels, raised tail water

*Corresponding author: manjurguku@gmail.com 
does not influence free flow add up to upstream head $\left(\mathrm{H}_{0}\right)$, known as particular submergence. At the point when this farthest point is surpassed, upstream aggregate head $\left(\mathrm{H}^{*}\right)$ builds in respect to $\mathrm{H}_{\mathrm{o}}$ for a given weir discharge $(\mathrm{Q})$, expanding potential upstream flooding. In customary submergence, tail water is more than weir crest which is caused by downstream control. In neighborhood submergence, lifted tail water happens when bay cycle discharge surpasses free flow limit of outlet cycles.

\subsection{Labyrinth weir}

Weir crest is a prominent characteristic of labyrinth weir. Labyrinth weir is not having linear plan form. Weir crest length reduces upstream head for a given discharge. A labyrinth weir has advantage when width of a channel is limited. Compact disc for labyrinth weir is lesser than direct weir. Because of increment in weir length, discharge builds 3-4 times [2] and discharge limit (Q) is relative to weir length (L) [3]. For labyrinth weirs, as the crest length expands, discharge increments for a given upstream head. They are utilized as control structures. It can be utilized where scope of discharges that have constrained variety in upstream water level. It is using pressurized water more effective spillway structure can oblige expanded base-flow repository stockpiling volumes without trading off surge wellbeing, which is helpful for water system, metropolitan and hydropower applications. Plan direction for applications (repository), in which moving toward flow field is non-uniform and isn't opposite to the weir hub[4], varying approach flow edges, flow joining, projection initiated flow constrictions, and the quantity of cycles can altogether impact weir discharge proficiency. Thought of labyrinth side weir was first exhibited by Emiroglu. It was accounted for that discharge co-proficient of labyrinth side weir is 1.5 to 4.5 times higher than typical rectangular side weir in a rectangular channel. Trapezoidal weir of labyrinth format is ideal contrasted with triangular weir [5]. Group of bends for outlining labyrinth weirs was built up [6]. Plan method for labyrinth spillways, where discharge coefficient esteems for labyrinth points between $6^{\circ}$ and $35^{\circ}$ are proposed [2] and their conditions are substantial for scope of widths amongst $\mathrm{T}_{\mathrm{s}}$ and $2 \mathrm{~T}_{\mathrm{s}}, \mathrm{T}_{\mathrm{s}}=$ wall thickness and $\mathrm{H} / \mathrm{P}<0.9$. Nappe is a fly like flow ignoring the weir which shows sticking, circulated air through, mostly circulated air through or suffocated (non-circulated air through) conditions which influence the discharge. Most Labyrinth weir plan techniques accessible are lab tried on flumes, in which the moving toward flow field is generally uniform and is opposite to the weir [2, 5, 7, and 8]. The labyrinth weir plan technique exhibited by Crookston [7] uses general weir condition and introduces coefficient of discharge for quarter-round and half-round labyrinth weirs for $6^{\circ}<\alpha<35^{\circ}$ is, $\mathrm{Q}=2 / 3^{*} \mathrm{C}_{\mathrm{d}} * \mathrm{~L} * \sqrt{2} \mathrm{~g} *$ $\left(\mathrm{H}_{\mathrm{t}}\right) 3 / 2$, where upstream head , $\mathrm{H}_{\mathrm{t}}=\mathrm{V}^{2} /(2 \mathrm{~g}+\mathrm{h})$. Labyrinth weir can be introduced in repository spillways in numerous arrangements viz., somewhat or completely anticipating, and adjusted channel, flush and arced. Houston [9] detailed that for a 2-cycle somewhat anticipating labyrinth weir introduction expanded Q by $10.4 \%$ in respect to a flush introduction with adjusted projections. The cycle arrangement of labyrinth weir however might be arced to better adjust the cycle introductions to the focalizing approach flow vectors and to additionally expand the weir crest length [10] and discharge efficiency [11]. Water driven productivity of Prado spillway could be expanded had the cycle design been bended to enhance the arrangement to the moving toward flow, introduction [12]. Be that as it may, for most in-channel applications, arced labyrinth weirs are not reasonable. The air entrainment rate is influenced by parameters like weir included edge $\theta$ and weir ledge slope $\Phi$. A specialist [13] showed 3 instruments of oxygen exchange for free falling water fly diving into an accepting pool. 
1. In the fly itself amid the fall, measure of oxygen exchange is little.

2. By means of free surface of getting water, relies upon power of surface tumult in accepting pool.

3. In air-water biphasic flow that exists inside accepting pool due to air diversion administered via air excitement rate by bubble contact time in water. The last instrument was most huge supporter of oxygenation process.

Tsang's [14] proposed 4 air stimulation instruments which are smooth, rough, oscillating and dis-integrated. Disintegrated planes have favorable position because of more prominent surface zone; however entrainment rate and air pocket infiltration are reduced as a result of vitality misfortune to encompassing environment amid fall. Numerous analysts [15-21] have completed research facility examinations concerning weir air circulation. Researchers [20-21] considered oxygen exchange proficiency of triangular and rectangular labyrinth weir sub-current rates fluctuating from 1 to $4 \mathrm{lps}$, demonstrated that weirs enhance air circulation qualities. Nappe might be insecure and create flow surging in labyrinth weir. Nappe obstruction signifies diminishment in labyrinth weir discharge proficiency caused by impacting or interfacing nappe's close upstream summit. Nearby submergence and nonopposite flow lines are in charge of labyrinth weir discharge coefficients being less then direct weirs (sideways weirs have bring down $\mathrm{C}_{\mathrm{d}}$ esteems contrasted with straight weirs). For smaller $\mathrm{H}_{\mathrm{t}}$, nappe communication happens downstream and no change is headdischarge connections. As $\mathrm{H}_{\mathrm{t}}$ increments, impacting nappe's make confined semi angled water powered hop condition and constrained discharge conveying limit close upstream end, which brings about nearby submergence. Neighborhood submergence starts close upstream zeniths of outlet and increments with $\mathrm{H}_{\mathrm{t}}$ until the point when it is submerged autonomous of downstream tail water. Pressure driven results of impacting labyrinth weir nappe's incorporate standing waves and air building in downstream cycles. Size of district impacted by nearby submergence and nappe crash differs with $\alpha$, A, crest shape, $\mathrm{P}, \mathrm{H}_{\mathrm{t}}$ and nappe air circulation. Labyrinth weirs are ordinarily intended for, yet not restricted to $\mathrm{H}_{t} / \mathrm{P}$ $<1$, where $\mathrm{H}_{\mathrm{t}}$ is add up to upstream head and $\mathrm{P}$ is weir stature. Geometric parameters influencing water powered plan are sidewall edge $(\alpha)$, number of cycles $(\mathrm{N})$, crest shape, upstream profundity, weir stature, weir length [12]. For considerable approach speed, estimation of discharge coefficient fluctuates with upstream head. Submergence connections in view of flow reduction factor $\mathrm{Q}_{s} / \mathrm{Q}_{1}$ and for sharp crested weirs as a component of submergence ratio $\mathrm{H}_{\mathrm{d}} / \mathrm{H}^{*}$ [22-26]. For labyrinth weir submergence, submergence flow magnification factor was bigger than free-flow magnification factor and presumed that submergence impacts are less noteworthy for labyrinth weirs than direct weirs. Head magnification factor can be changed over to flow lessening factor and the other way around. Disadvantages of customary labyrinth weirs is high constructional costs, can't be effortlessly put on crest of basic solid gravity dams, reduction of discharge limit with expanding the nappe stature when the weir included edge is picked too little and as number of cycle's increments due to nappe crash and neighborhood submergence. To expand the dependability of the structure, base of the keys are sloped. Outline methods proposed for labyrinth weirs are not pertinent for PK weirs. PK weir is a productive arrangement. 


\subsection{Piano Key Weir}

PKW is a type of labyrinth weir [27] with productive hydraulic performance, particularly at low heads. It has upstream and downstream overhangs of variable width to lessen footprint area [28] to enable easy weir location on a top of a dam crest of existing dams and new gravity dams unlike conventional weirs, where submergence isn't a factor. The first scale display examines demonstrated that this present PKW's discharge capacity [29] and efficiency is up to four times than a conventional ogee-crested weir at rise to head, crest length and same width [30] and 10\% higher than labyrinth weir of same crest impression [31].The PKW has inlet and outlet base inclines, 2 transversal dividers with channel and outlets. PKW has sloped up-and downstream key floors. PK weir geometry impacts hydraulic efficiency and performance [32]. Its principle geometric parameters are weir height $\mathrm{P}$, the quantity of PKW units $\mathrm{N}_{\mathrm{u}}, \mathrm{PKW}$ unit width $\mathrm{W}_{\mathrm{u}}$, lateral or side crest length $\mathrm{B}$, inlet and outlet key widths $W_{i}$ and $W_{o}$, upstream and downstream overhang lengths $B_{o}$ and $B_{i}$, wall thickness $T_{s}[33]$. Expanding the inlet or outlet width ratio $W_{i} / W_{o}$, the upstream overhang length $\mathrm{B}_{\mathrm{o}}$ and the weir stature $\mathrm{P}$, shape of upstream overhang, the developed length to width ratio (L/W) were considered to improve the discharge limit and performance [34-35]. Investigation of execution of PKW in perspective of air circulation limit and floating debris section was proposed [30].The floating debris will effectively disregard as the water level expands [30]. The first model size PKW was worked by Electricité de France (EDF) amid 2006 to build the discharge limit of the Golours dam spillway [36]. They are high performance and practical answer for new dam ventures, in which space and accessible repository portion are restricted, contrasted with design discharge to be released. PK weir would likely deliver higher aggregate weir discharge attributable to its smaller compact geometry (large weir length for a given base area). The surge discharge estimations and security issues of countless dams require spillway recovery since a few dams have little spillway limits. PKW is a novel type of weir created by Blanc and Lempérière (2011)[28, 37]. EDF favored the utilization of PKW in dam recovery in France. Later on, two PKW's were based on St. Marc and Gloriettes dams in 2008 and 2009[38, 39] and at Etroit dam to overhaul spillway limit [40]. Sri Lanka's first spillway was developed at Giritale in 2013. PK weirs limit upstream immersion because of its improved low head surge discharge productivity. 1-D show was produced at college of Liège to enhance its outline [41]. Most of the dams claimed by EDF have short hydrological records. A few elements considered are: cost, expulsion of huge amounts of cement or adding new loads to existing structures, energy dissemination structures, lessening energy generation amid development works. Advantages of PKW are the expansion of the aggregate successful crest length for a given width [28]. It is utilized to build discharge limit with respect to a given head or abatement the set out toward a given discharge, because of generally vast anticipated spillway length. Henceforth, it altogether decreases the afflux and limits danger of upstream flooding. It permits high crest level which can expand the capacity limit in the store. Moreover, past prudent thought, PKW's are free flow spillways and have a high level of safety and reliability beyond cost consideration. Favorable position of PKW as contrasted and a labyrinth weir are reduced footprint base area and because of inside slopes in the alveoli, decreases the force following up on sidelong dividers and consequently the basic structural cost. In 2011, EDF began to extend information on some optional parameters, for example, the overhangs, the crest shape, and the dam stature. The program incorporates testing of trapezoidal shape with a side divider point of the parallel dividers to contrast water powered execution with rectangle shape. The majority of the analyses were completed under free-flow conditions. It was discovered that, discharge limit of PK weir could be enhanced by including plan changes (adjusted noses on upstream summits, parapet divider, enhanced crest shapes) [32]. 
Extra weir length can be created with a PKW, by cantilevering both the up-and downstream keys past the basic impression. Classifications of PKW based on geometry are: Type A, in which up-and downstream finished overhangs are indistinguishable, Type B in which there is only upstream overhang, Type $\mathrm{C}$ in which there is only downstream overhang, Type $\mathrm{D}$ in which there is sloped floor and has no overhang. Type-A PK weir are using pressurized water more efficient than rectangular labyrinth weir with same crest length [42]. Type B geometry is more proficient than Type A for PK weirs [43]. A few specialists [44, 45] have proposed for ideal outline $\mathrm{W}_{\mathrm{i}} / \mathrm{W}_{\mathrm{o}}=1.2$ where $\mathrm{W}_{\mathrm{i}}$ and $\mathrm{W}_{\mathrm{o}}$ are widths of downstream and upstream summits. Hein [45] found that PKW geometry is for the most part more powerful than trapezoidal labyrinth weir for nappe aeration on account of overhang geometry. Trapezoidal labyrinth weirs regularly give more discharge limit per unit weir length than PK weirs [32]. An absence of understanding endures in regards to prevailing flow conditions, because of expansive number of geometric parameters and absence of thorough examination of the discharge coefficient [31, 46]. Some institutionalized plans are accessible for the PKW [47]. A scientist [46] empowered to portray the flow on the structure as far as velocity, pressure, free surface levels and flow patterns. Submergence (S) is the ratio of aggregate downstream head $\left(\mathrm{H}_{\mathrm{d}}\right)$ to add up to submerged flow upstream head $\left(\mathrm{H}^{*}\right), \mathrm{S}=\mathrm{H}_{\mathrm{d}} / \mathrm{H}^{*}$. As $\mathrm{H}_{\mathrm{d}}$ value rises, it approaches $\mathrm{H}^{*}$, where weir never again goes about as control structure. Use of parapet dividers demonstrated increment in discharge limit up to $15 \%$ on Etroit Dam[38], yet the effectiveness of these structures has just been contemplated on single PKW setup with or without parapet dividers changing aggregate weir stature ratio $\mathrm{P} /\left(\mathrm{B}-\mathrm{B}_{\mathrm{o}}\right)$ from 0.58 to 0.65 . In a similar scope of slopes, if the PKW height is adjusted by changing slope of channel and outlet base inclines, instigates comparable varieties in discharge limit [48]. It isn't clear to the point that, PKW with parapet dividers is in reality more effective that standard PKW having same aggregate height.

\section{Literature survey}

Construction of PKW can be made using reinforced concrete, steel or other mixed materials. PKW prototype can be fabricated using PVC, acrylic sheet. Water is allowed to flow to stabilize the weir and allow thermal contraction of acrylic sheet. Care should be taken by reducing reinforcement quality, improve concrete durability through concrete cover increase, increase PKW stiffness, structural response to dynamic loads due to flow vibrations while using reinforced concrete walls. Laboratory scale labyrinth weir can be fabricated using high density polyethylene (HDPE).

\subsection{LABYRINTH WEIR}

As crest effectiveness diminishes, $\mathrm{C}_{\mathrm{dl}}$ turns out to be less imperative with expanding head which is seen in trapezoidal labyrinth weirs with impact of angle $\alpha$ between lateral crest and principle stream direction [2]. Compared to $\alpha=12^{\circ}$ (downstream cycle sidewall angle) the reduction in efficiency was more rapid for $\alpha=6^{\circ}$, where upstream cycle flow area was significantly larger [11]. For labyrinth weirs, diminishing of $\mathrm{Cd}$ with head is essential for small values of $\alpha$ and it causes increment of $\mathrm{L} / \mathrm{W}$. Weir efficiency is distinguished by $\mathrm{C}_{\mathrm{dl}}$ gain with reduction of $\alpha$. To circumvent lateral crest submergence; increment the inlet channel width till outlet width is sufficient ([30], Michael's), the inlet slope or inlet height utilizing crest appendage to build $\mathrm{C}_{\mathrm{d}}[30,34]$. An expansion in inlet channel cross-section expands head needed to create control section. As number of cycles $(\mathrm{N})$ builds, impact of abutment-induced flow on discharge efficiency diminishes. L/B, $\theta$ affects discharge 
capacity of labyrinth side weir. Q for labyrinth side weir increases with reducing $\theta$. As $\theta$ increases, cycle orientation is improved and spillway efficiency increases.

\subsubsection{Effect of orientation and configuration}

Discharge capacity of arced labyrinth weirs are significantly higher than horse shoe weir ( $\sim 690$ and $380 \%$ for $\alpha=6^{\circ}, \alpha=12^{\circ}$ respectively), because of significantly longer crest length. Flush discharge efficiency is reduced by as much as $11 \%$ for $\alpha=12^{0}$, in-channel labyrinth weir configuration. To enhance discharge efficiency of rounded inlet, abutment wall radius should be increased. Rounded inlet and projecting geometries are more productive than in-channel labyrinth weir at lesser $\mathrm{Ht} / \mathrm{P}$ and are less proficient ( $5-7 \%$ ) at higher $\mathrm{H}_{\mathrm{t}} / \mathrm{P}$ values. For $\mathrm{H}_{\mathrm{t}} / \mathrm{P}>0.15, \alpha=120^{\circ}$, projecting labyrinth weirs are $\sim 2$ to $5 \%$ less effective with respect to in-channel and for $\alpha=6^{\circ}$, it is $10 \%$ less proficient for $\mathrm{Ht} / \mathrm{P}>0.25$. Projecting configuration shows increased discharge efficiency as compared to in-channel labyrinth weir which is limited to $\mathrm{H}_{t} / \mathrm{P}<0.5$. Arced configuration of a labyrinth weir improves discharge efficiency of 5-11\%. Discharge limit of arced labyrinth weirs are essentially higher than horse shoe weir ( $\sim 690$ and $380 \%$ for $\alpha=6^{\circ}$, $\alpha=12^{\circ}$ separately), on account of significantly longer crest length. Arced design configuration requires larger base area than projecting configuration setup. Flush orientation has minimum efficiency while arced orientation has most noteworthy efficiency.

\subsubsection{Effect of nappe}

For $\mathrm{H} / \mathrm{P}=0.1$, low head; $\mathrm{H} / \mathrm{P}=0.2$, transition head; $0.35<\mathrm{H} / \mathrm{P}<0.5$, high head. At lower value of heads, transition from partially clinging to leaping to springing nappe, depends on rising head, crest thickness and crest shape. For $\mathrm{H} / \mathrm{P}=0.05$, leaping nappe remains in contact with the lateral crest. For $0.09 \leq \mathrm{H} / \mathrm{P} \leq 0.1$, springing free nappe is observed and it continues till it reaches high head. At low heads, inlet slopes has no effect on nappe shape and transition from leaping to springing nappe occurs at $0.11 \leq \mathrm{H} / \mathrm{P} \leq 0.12$. Overpressure head increases with the upstream head. Flow behavior of upstream head is different from downstream and lateral head. It is observed that, $0.16 \leq \mathrm{H} / \mathrm{P} \leq 0.17$, nappe is fully aerated. Downstream nappe slope has significant effect on nappe shape. For moderately low heads $(\mathrm{H} / \mathrm{P} \leq 0.2)$ streamlines are homogenously distributed. For $\mathrm{H} / \mathrm{P}>0.2$, streamline distribution is less optimal. $\mathrm{C}_{d}$ value increases at $\mathrm{H}_{t} / \mathrm{P} \sim 0.25$ due to nappe shifting from non-aerated to aerated. $\mathrm{H}^{*} / \mathrm{Ho} v / \mathrm{s} \mathrm{H}_{\mathrm{d}} / \mathrm{H}_{\mathrm{o}}$ is a function of $\mathrm{H}_{\mathrm{o}} / \mathrm{P}$, and as it builds up, weirs become less susceptible to submergence. $\mathrm{H}^{*} / \mathrm{H}_{\mathrm{o}}$ v/s $\mathrm{H}_{\mathrm{d}} / \mathrm{H}_{\mathrm{o}}$ is accurate compared to Ville Monte relationship in predicting total upstream head on submerged labyrinth weir, for different side wall angles. As sidewall angle is increased submerged labyrinth weir approaches linear weir. Tullis observed that as $\mathrm{C}_{\mathrm{d}}$ diminishes, nappe height increases. For $L / b=0.5$, variation of $C_{d}$ is insignificant against $F_{1}$, but it is vice versa for $L / b=1$. Length of side weir and Froude number $F_{1}$, crest height of side weir affect the secondary flow. Increase of secondary flow maybe created due to lateral flow and it is due to growth of deviation angle and kinetic energy towards side of weir. 


\subsubsection{Effect of velocity profiles}

For $\mathrm{H} / \mathrm{P}=0.1$ and 0.2 , velocity profiles are relatively uniform along lateral and the inlet center. Velocities increases, for $\mathrm{H} / \mathrm{P}=0.35$ and 0.5 along sidewall and inlet centers.

\subsubsection{Effect of recirculation zone, turbulence}

Non-rectangular front part appearance of upstream overhangs diminishes re-circulation zone size and thus discharge limit increments. As approach flow angle drifts from right angle to labyrinth weir axis it produces wake induced turbulence close to upstream apex.

\subsubsection{Effect of submergence}

I. Compared to linear weir, labyrinth weir is less influenced by submergence which is consistent with Taylor's observations (1968). At the same submergence, flow reduction of labyrinth weir is less than linear weir. As per our review, when $\mathrm{H}^{*}$ approximately reaches $\mathrm{H}_{0}$, for $\mathrm{S}<\sim 0.48$ (Modular Submergence), tail water submergence effects don't influence free flow head discharge relationship till total head exceeds $48 \%$ of upstream total head. Local submergence is contributes to nappe interference.

II. Local submergence of labyrinth weir is observed at $\mathrm{H}_{\mathrm{t}} / \mathrm{P}=0.6$, and $\mathrm{C}_{\mathrm{d}}$ is significantly less than linear weir, but it has high discharge capacity of $270 \%$ and $180 \%$ for $\alpha=6^{0}, 12^{0}$ respectively.

\subsubsection{Effect of jet overcrossing}

As the head increases there is loss of effective crest length, also efficiency decreases due to lateral jet over crossing.

\subsection{PK WEIR}

Weir equations:

Because of unpredictability of PKW geometry, weir equation head v/s weir length as,

$$
Q=C_{d w} * W * \sqrt{ } 2 g H^{3} \text {, where } W=1.5\left(W_{i}+W_{o}\right)+3 * T_{s}
$$

Co-efficient of discharge is also affected by ratio of $\left(\mathrm{h}_{1}-\mathrm{p}\right) / \mathrm{p}$, weir included angles.

$$
C_{p k w}=f\left(L / W, a_{1} / b_{1}, P / a_{1}, P / P^{l}, T_{s} / P, T_{S} / R, H / a_{1}, S_{i n}, S_{o u t}, F_{1}, R, w\right)
$$

Total discharge,

$$
Q=f\left(\rho, g, v, \sigma, H, L, P, P^{l}, W, a_{1}, b_{1}, B_{1}, S_{\text {in }}, S_{\text {out }}, T_{s}, R, \alpha\right)
$$

Discharge coefficient of crest given by Swamee (1988) is,

$$
C_{d l}=\frac{3}{2} * C_{d w} * W / L
$$




$$
\frac{L}{W}=\frac{a 1+b 1+2 B}{a 1+b 1}
$$

In General,

$$
H^{*} / H_{o}=A^{*}\left(H_{d} / H_{o}\right)^{B}+C^{*} e^{D\left(H_{d}{ }^{\prime H}\right)}
$$

Crest length amplification proportion is signification. For same proportion H/a, most elevated estimations of ' $r$ ' discharge enhancement proportion, are identified with higher estimations of L/W. As H (H/a) builds, efficiency diminishes. Smaller estimations of P, reduce efficiency. Jet over-crossing is because of $\mathrm{H}, \mathrm{b}, \mathrm{P}$ and outlet suffocating because of powerlessness to clear stream-wise stream. For given $\mathrm{H} / \mathrm{P}, \mathrm{L} / \mathrm{W}$ isn't imperative. ' $\mathrm{r}$ ' is figured for a given estimation of width $(\mathrm{W})$ and highest value of height of weir. $\mathrm{T}_{\mathrm{s}} / \mathrm{P}$ and $\mathrm{T}_{\mathrm{s}} / \mathrm{R}$ are important for low heads. For Gloriettes model, $\mathrm{L} / \mathrm{W}=5.6$, has lowest specific discharge [49].

Surface tension effects may become significant for $\mathrm{H} / \mathrm{P}<0.06[50]$. The smaller the weir dimension more important is $\mathrm{H} / \mathrm{T}_{\mathrm{s}}$ at transition from leaping to springing nappe [51].To eliminate surface tension effect and to ensure that free surface is undular, the ratio of $\mathrm{H} / \mathrm{P}$ should be optimal.

\subsubsection{Effect of velocity profiles}

Lateral discharge is a function of water height over lateral crest and velocity in inlet direction, and it can be reduced since inertia effect is related to velocity in direction of inlet key [52].

By increasing slope of inlet and outlet, PKW efficiency decreases. For $\mathrm{H} / \mathrm{P}<0.15$ there is reduction in discharge coefficient at low heads. TPKW's design constraint was to maximize side wall angle $\alpha$, keeping $\mathrm{L} / \mathrm{W}$ constant, which is a prominent parameter for PKW performance. Upstream and downstream length (B) of TPKW influences the building cost. Better hydraulic performance is observed by half - round and quarterround shapes compared to flat-top shape, which is validated by Anderson. It is suggested that half and quarter round shapes should be built on lateral crest, flat top shapes should be built on upstream and downstream crest. No matter the position of rounded face, quarter-round shape on lateral crest has same discharge efficiency. Sharp and broad crested weir is less efficient than Ogee crest weir and PKW is more efficient than ogee crest by $30 \%-60 \%$ for type A, $10-70 \%$ for type B and $5-45 \%$ for type C. It was found that [53], for weir included angle $45^{\circ}$ and $60^{\circ}, C_{d}$ value is greater than for angles, $\theta=90^{\circ}, 120^{\circ}, 150^{\circ}$.

PKW is identified with lessening inlet flow constriction, approach velocity and head loss entering the inlet owing to increment in wetted perimeter related to apex overhang. In outlet keys, increment in flow area and wetted edge enables water to leave more efficiently. To build outlet cycle discharge limit by diminishing submergence, incorporates expanding downstream apron slope, bringing down downstream apron elevation or enhancing downstream cycle footprint. 


\subsubsection{Effect of submergence}

For PK weir, as submergence level rises, it stops behaving as head discharge control structure, which is at lower $\mathrm{H}_{d} / \mathrm{H}_{\mathrm{o}}$ values, as $\mathrm{H}_{\mathrm{o}} / \mathrm{P}$ increases. For larger values of $\mathrm{S}$, submerged PKW turns out to be less effective than labyrinth weir. With respect to labyrinth weir submergence behavior, scope of $\mathrm{H}_{\mathrm{d}} / \mathrm{H}_{0}$ for which PKW is less sensitive to submergence effects expanded with increasing $\mathrm{H}_{\mathrm{o}} / \mathrm{P}$. Little increment in discharge efficiency happens as PKW changes between free flow and modular submergence. (Oamane 2011 found similar observation).

\subsubsection{Effect of suction}

PKW behaves like sharp crested weir for low heads since suction effect is starting, and hence discharge increases.

\subsubsection{Effect of parapet walls}

Flow submergence is retarded due to presence of raised side walls at low heads and it increases discharge capacity upto $15 \%$, especially at downstream crest. The efficiency of parapet wall depends on weir height and $\mathrm{W}_{\mathrm{i}} / \mathrm{W}_{\mathrm{o}}$ [52]. Hence there is no direct effect on discharge capacity of the key slopes. Weir height without parapet wall is important to reduce longitudinal velocity. On increasing the height by parapet wall, velocity and lateral discharge are not changed but is induced by water height over lateral crest.

\subsubsection{Effect of dimensionless parameters}

If Froude's number $F_{1}<1$, the flow is said to be subcritical. $C_{d}$ decreases with increase in $\left(h_{1}-p\right) / p$, increase in Froude number; decreases weir included angle. Reynolds number $(\mathrm{R})$ and Weber number $\left(\mathrm{w}_{1}\right)$ are maintained sufficiently large in order to avoid liquid viscosity and surface tension effects.

\section{Conclusions}

When compared with other solutions, the PKW has a number of advantages, no change of normal and maximum operating levels, minor impact on dam structure, no impact on existing gate and other mechanical components, reliability of free flow spillway, requiring little maintenance and low cost solution involving the construction of simple concrete units [49]. Experimental investigations were performed on models of various types of PKWs. The results indicate that an increase of the downstream key width results in an increase of the discharge capacity. Consequently, decrease in the upstream key width results in an increase of the local submergence of the upstream key and a decrease of its discharge efficiency. The upstream weir overhangs significantly increase the discharge coefficient. The upstream weir overhang increases the inlet flow area and the wetted perimeter, resulting in reduced inlet velocities, flow contraction and energy loss [54]. The model studies clearly shows that the number of keys and the crest shape of the weirs were two 
parameters that had a significant bearing on model performance. The PK spillway shows great promise in significantly improving the existing flood discharge capacities of spillways at dams such as Nachchaduwa, which experienced critical conditions in 2011 and 2014 [55]. The main influence of a parapet wall on a PKW crest is an increase of the total PKW height. The use of a parapet wall, increasing the total weir height to approach its optimal value, has been shown to increase the discharge capacity of the PKW. The main effect of the parapet walls is to increase the inlet height and, hence to reduce the longitudinal velocity, resulting in an increase of the lateral discharge. However, the height of the parapet wall has to be limited to maintain the interest of overhang use, limiting the head losses at the inlet key entrance. Increasing the parapet wall height so decreases the PKW discharge capacity until the one of a labyrinth weir with the same horizontal shape. PKW is more convenient and cost-effective to use standard PKW without parapet walls. However, parapet walls provide a good opportunity for future PKW rehabilitations, enabling, in some cases, an increase in the discharge of the initial PKW by up to $20 \%$ by a limited increase of the maximal reservoir level [52]. The discharge capacity of TPKW is greater than the rectangular plan form. Among the geometrical ratios, $\mathrm{W}_{\mathrm{i}} / \mathrm{W}_{0}$ and $\mathrm{L} / \mathrm{W}$ were found to have the lowest and highest influence on increasing the $C_{d}$ value respectively. For a given head $(\mathrm{H})$, the weir discharge increases for higher $\mathrm{P}$ values remarkably. Regardless of the $\mathrm{L} / \mathrm{W}$ value, the peak value for $C_{d}$ corresponds to $H / P$ ratio. Operation of a weir under nappe or transition flow regime with high efficiency is preferable [56].

\section{Notations}

$\mathrm{A}=$ inside apex width

B = lateral crest length or weir sidewall length

$\mathrm{B}_{\mathrm{i}}=$ downstream overhang length

$\mathrm{B}_{\mathrm{o}}=$ upstream overhang length

$\mathrm{L}=$ developed weir crest length

$\mathrm{N}_{\mathrm{u}}=$ number of PKW units

$\mathrm{P}=$ weir wall height

$\mathrm{S}_{\text {in }}=$ inlet key bottom floor slope

$\mathrm{S}_{\text {out }}=$ outlet key bottom floor slope

$T_{\mathrm{s}}=$ vertical wall thickness of the weir

$\mathrm{W}=$ weir channel width 
$\mathrm{W}_{\mathrm{i}}=$ inlet key width

$\mathrm{W}_{\mathrm{o}}=$ outlet key width

$\mathrm{C}_{\mathrm{d}}=$ discharge coefficient

$\mathrm{g}=$ acceleration due to gravity

$\mathrm{h}=$ piezometric head

$\mathrm{H}_{\mathrm{d}} / \mathrm{H}_{\mathrm{o}}=$ ratio of submerged total downstream head and the total free-flow head relative to the weir crest

$\mathrm{H}^{*} / \mathrm{H}_{\mathrm{o}}=$ ratio of total submerged head and the total free-flow head measured at a common flow rate relative to the weir crest elevation.

$\mathrm{Q}=$ discharge over weir

$\mathrm{S}=$ submergence factor

$\mathrm{V}=$ flow velocity

$\mathrm{w}=$ cycle width for a weir

$\alpha=$ sidewall angle

$\mathrm{H}_{\mathrm{t}} / \mathrm{P}=\mathrm{H} / \mathrm{P}=$ headwater ratio

$\mathrm{a} 1, \mathrm{a}_{1}=$ upstream key width

$\mathrm{b} 1, \mathrm{~b}_{1}=$ downstream key width

$\mathrm{B}_{1}=$ length of side weir

$\mathrm{P}^{\prime}=$ approach flow depth

$v=$ kinematic viscosity

$\rho=$ density of water

$\sigma=$ surface tension

$\theta=$ weir included angle

$\alpha^{\prime}=$ upstream weir side wall angle $=\alpha+\theta / 2 \theta=\Theta / \mathrm{N}$ 


$$
\begin{aligned}
& \Theta=\text { arced labyrinth weir angle } \\
& \mathrm{N}=\text { weir cycle number } \\
& \mathrm{C}_{\mathrm{dl}}=\text { discharge coefficient of crest } \\
& \mathrm{C}_{\mathrm{dw}}=\text { discharge coefficient of weir } \\
& \mathrm{F}_{1}=\text { Froude's number } \\
& \mathrm{w}_{1}=\text { Weber number } \\
& \mathrm{R}=\text { Reynolds' number } \\
& \Phi=\text { weir ledge slope }
\end{aligned}
$$

\section{References}

1. Kirkpatrick, K.W. "Discharge coefficients for spillways at TVA dams." Trans. Am. Soc. Civ. Eng., 122,190-210, (1957).

2. Tullis, B.P., Amanian, N., and Waldron, D. "Design of labyrinth weir spillways." J. Hydraul. Eng. 121(3), 247-255, (1995).

3. Henderson, F.M. "Open channel flow." Channel controls, MacMillan, New York, 174176. (1966).

4. Copel and, R., and Fletcher, B. "Model Study of Prado Spillway, California, Hydraulic model investigation Rep. ERDC /CHL TR-00-17, U.S. Army corps of Engineers Research and Development Centre Vicksburg, MS (2000).

5. Hay, N., and Taylor, G. "Performance and design of labyrinth weirs.“ J. Hydrol Eng., 96(11), 2337-2357, (1970).

6. Darvas, L.A. "Discussion of performance and design of labyrinth weirs by Hay and Taylor.” J. Hydro. Div., 97 (8), 1246-1251 (1971).

7. Crookston, B.M. "Labyrinth weirs." Ph.D. dissertation, Utah State Univ., Logan, UT (2010).

8. Magalhães, A., and Lorena, M. "Hydraulic design of labyrinth weirs." Rep. No. 736 National laboratory of civil Engineering, Lisbon, Portugal (1989).

9. Houston, K. "Hydraulic model study of Hyrum Dam auxiliary labyrinth spillways." Rep. No. GR-82-13, U.S Bureau of Reclamation Denver, Co. (1983).

10. Cassidy, J. "Labyrinth crests spillway planning design and construction." Int. conf. on hydraulic aspects of Floods and Flood control, city Univ., London (1983).

11. Page, D., Garcia, V., and Ninot, C. "Aliviaderos en laberinto. presa de Maria Cristina." Ingenieria Civil, 146, 5-20 (in Spanish) (2007).

12. Falvey, H.T. "Hydraulic design of labyrinth weirs." ASCE Reston VA (2003).

13. Gameson, A.L.H. "Weirs and aeration of rivers." J. Inst. Water Eng., 11 (1957).

14. Tsang, C.C. "Hydraulic and aeration performance of labyrinth weirs." Ph.D., thesis, Univ. of London, (1987). 
15. Van-der kroon, G.T.N., and Schram A.H. "Weir aeration. I: H2O." 22, 528-537 (1969a). Van-der Kroon, G.T.N., and Schram, A.H. “weir aeration. II: H2O.” 22, 538545 (1969b).

16. Apted, R.W., and Novak, P. "Some studies of oxygen uptake at weirs." Proc. 15th congress, IAHR Paper B23.V (1973).

17. Avery, S., and Novak, P. "Oxygen transfer at hydraulic structures." J. Hydraul. Div., Am. Soc. Civ. Eng., 104 (11) 1521-1540 (1978).

18. Thene, J.R. "Gas transfer at weirs using the hydrocarbon gas tracer method with headspace analysis." MSc thesis, Univ. of Minnesota, (1988).

19. Labocha, M., Corsi, R.L., and Zytner, R.G. "Parameters influencing oxygen uptake at clarifier weirs.” Water Environ. Res., 68(6), 988-994 (1996).

20. Wormleaton, P.R., and Soufiani, E. "Aeration performance of triangular plan form labyrinth weirs.” J. Environ. Eng., 124(8), 709-719 (1998).

21. Wormleaton, P.R., and Tsang, C.C. "Aeration performance of rectangular plan form labyrinth weir.” J. Environ. Eng., 126(5), 456-465 (2000).

22. Bazin, H. "Experiences nouvelles sur l' écoulement en déversoir." Vol.VII, Annales des Points et Chausses, Memories et documents (1894).

23. Cox, G.N. "The submerged weir as a measuring device." Bulletin engineering experiment station series no. 67, Univ. of Winconsin, Madison, wis. (1928).

24. Francis, J.B. "Experiments on the flow of water over submerged weirs." Trans. Am. Soc. Civ. Eng., 13, 303-312, (1884).

25. Fteley, A., and Stearns, F.P. "Description of some experiments on flow of water made during the construction of works for conveying water of Sudbury River to Boston." Trans. Am. Soc. Civ. Eng., 12, 101-108, (1883).

26. Ville Monte, J.R. "submerged weir discharge studies.” Eng. New-Rec., 139 (26), 5456, (1947).

27. Tullis, B.P., Young, J.C and Chandler, M.A. "Head-discharge relationships for submerged labyrinth weirs." J. of Hydraul. Eng., 133 (3), 248-254, (2007).

28. Lempérière, F. and Ouamane, A. The piano keys weir: a new cost-effective solution for spillways. Hydro power and Dams Issue 5, 144-149, (2003).

29. Lempérière, F., Ouamane, A. "The piano keys weir: a new cost-effective solution for spillways.” Int. J. Hydropower and Dams 10 (5), 144-149 (2003).

30. Ouamane, A. and Lempérière F. "Design of a new economic shape of weir'. Proceedings of the international symposium on Dams in the societies of the $21 \mathrm{st}$ century, 463-470. Barcelona, Spain (2006).

31. Anderson, R.M. and Tullis, B.P. "Influence of PKW geometry on discharge." In: Liege, S.E., Laugier, F., Boillat, J.İ., Pirotton, M., Reverchon, B. and Schleiss, A.J., Eds., Proc. Int. Work. Labyrinth and PK weirs PKW 2011, CRC press, London, 75-80, (2011).

32. Anderson, R.M. "Piano key weir head discharge relationships." M.Sc. Thesis, Utah state Univ. Logan, UT (2011).

33. Pralong, J., Vermeulen, J., Laugier, F., Erpicum, S., Boillat, J.L. "A naming convention for the piano key weir geometrical parameters." Proc. Int. Workshop labyrinth and piano key weirs Liège B, 256-263, (2011).

34. Ouamane, A., Lempérière, F. "Nouvelle conception de déversoir pour l'accroissement de la capacitè des retenues des barrages [New weir conception to increase dam 
reservoir capacities].” Proc. Coll. Int. Protection et Préservation des Resources en Eau, Blida, Algérie, 59-67 [in French], (2006b).

35. Le Doucen, O., Leite Ribeiro, M., Boillat, J.-L., Schleiss, A Laugier, F. "Etude Paramétrique de la capacité des PK-weirs [Parametric study of PK-weir capacity]." Proc. Modèles physiques hydrauliques : Outils indispensables du XXIe siècle, Lyon, 155-160. SHF, Paris (in French), (2009).

36. Laugie, F. "Design and construction of the first piano key weir spillway at the Goulours Dam.” Hydropower and Dams 14(5), 94-101, (2007).

37. Blanc, P., Lempérière, F. "Labyrinth spillways have a promising future." Hydropower and Dams 8(4), 129-131, (2001).

38. Bieri, M., Leite Ribeiro, M., Boillat, J.-L., Schleiss, A., Laugier, F., Delorme, F., Villard, J.-F. "Rehabilitation de la capacitè d'evacuation des crues: Intégration de $<<$ PK-Weirs $>>$ sur des barrages existants (Rehabilitation of floods discharge capacity: Integration of $<<\mathrm{PK}-$ Weirs $>>$ on existing dams)." Proc. Colloque CFBR-SHF: Dimensionnement et fonctionnement des évacuateurs de crues. SHF, Paris (in French), (2009).

39. Laugier, F., Lochu, A., Gille, C., Leite Ribeiro, M., Boillat, J.-L. "Design and construction of a labyrinth PKW spillway at Saint-Marc Dam, France." Hydropower and Dams, 16(5), 100-107, (2009).

40. Vermeulen, J., Laugier, F., Faramond, L. and Gilles, C. "Lessons learnt from design and construction of EDF first Piano Key weirs." Pro. International workshop on labyrinths and piano key weirs PKW 2011, CPC press, 215-224, (2011).

41. Erpicum, S., Machiels, o., Archambeau, P., Dewals, B.J., Pirotton, M. "ID numerical approach to model the flow over a Piano key weir." Proc. Sim Hydro 2010 Nice. SHF, Paris. (2010).

42. Anderson, R.M., and Tullis, B.P. "Comparison of Piano key and rectangular labyrinth weir hydraulics.” J. Hydraul. Eng. 138 (4), 358-361. (2012).

43. Lempérière, F. "New labyrinth weirs triple the spillways discharge." (http://www.hydrocoop.org). (2010).

44. Lempérière, F., Jun, G. "Low cost increase of dam storage and flood mitigation: the Piano keys weir." Proc. 19th congress Int.comm. Irrig. Drain. Beijng, 1-19, (2005).

45. Hien, T.C., Son, H.T., Khanh, M.H.T. Results of some piano keys weir hydraulic model test in Vietnam. Proc. 22nd I COLD Congress Barcelona Q87 (R 39), 581-596 (2006).

46. Machiels, O., Erpicum, S., Dewals, B., Archambeau, P. and Pirotton, M. "Experimental observation of flow characteristics over a PKW." J. Hydraulic res, 49, 359-366, (2011).

47. Machiels, O., Erpicum, S., Archambeau, P., Denals, B.J., Pirotton, M. "Piano key weir preliminary design method: Application to a new dam project." Proc. Int. conf. Labyrinth and Piano key weirs Liege B, 199-206 (2011).

48. Machiels, O., Erpicum, S., Archambeau, P., Dewals, B.J., and Pirotton, M. "Influence of Piano key weir height on its discharge capacity." Labyrinth 2nd piano key weirs, CRC Press, London, 59-66. (2011).

49. Marcelo LEITE RIBEIRO, Martin BIERI, Jean-Louis BOILLAT, Anton J. SCHLEISS, F. DELORME, F. LAUGIER. "Hydraulic capacity improvement of existing spillways-Design of piano key weirs." VINGT TROISIEME CONGRES DES GRANDS BARRAGES Brasilia, (2009). 
50. Novak, P., Moffat, A.I.B., Nalluri, C. and Narayanan R. Hydraulic structures Unwin Hyman, London, UK [Google Scholar] (1990).

51. Johnson, M.C. "Discharge coefficient analysis for flat-topped and sharp-crested layers.” Irrigation Science, 19(3), 133-137, (2000).

52. O. Machiels; P. Archambeau; B. Dewals, and M. Pirotton. "Parapet wall effect on piano key weir efficiency." J. of Irrigation and drainage Eng., 506, (2013).

53. Emiroglu ME, Kaya N, Agaccioglu H. "Discharge capacity of labyrinth side weir located on a straight Channel." Journal of irrigation and drainage engineering 2010; 136 (1): 37-46.

54. Abdorreza, Kabiri, Samani, and Amir Javaheri. "Discharge coefficients for free and submerged flow over piano key weirs.” J. Hydraul. Res., 50:1, 114-120 (2012).

55. R.A.R.V.Krishantha, S.S. Wickramasuriya. "Climate change adaptation: A Hydraulic model study to improve the spillway discharge of genital reservoir." G78-1-47991740-2/15/\$31.00@2015 IEEE. (2015).

56. A.Mehboudi, J. Attari, S.A. Hosseini. "Experimental study of discharge coefficient for trapezoidal piano key

http://dx.doi.org/10.1016/j.flowmeasinst.2016.06.005 (2016). 